\title{
Correspondence
}

\section{Comment on: Mid-Holocene water-level changes in the lower Rhine-Meuse delta (western Netherlands): implications for the reconstruction of relative mean sea-level rise, palaeoriver-gradients and coastal evolution by Van de Plassche et al. (2010)}

\author{
M.P. Hijma ${ }^{1}$ \& K.M. Cohen ${ }^{2,3}$
}

1 Tulane University, School of Science and Engineering, Department of Earth and Environmental Sciences, 6823 St. Charles Avenue, 101 Blessey Hall, New Orleans, LA, USA. Email: mhijma@tulane.edu.

2 Utrecht University, Faculty of Geosciences, Department of Physical Geography, P.0. Box 80115, 3508 TC, Utrecht, the Netherlands.

3 Deltares, Division BGS, Department of Applied Geology and Geophysics, P.0. Box 85467, 3508 TC, Utrecht, the Netherlands.

In May 2009, Orson van de Plassche sadly passed away. In a paper of which parts, especially the discussion section, were written after his death, new data and a revision of an existing sea-level curve are presented for the Rotterdam area (Van de Plassche et al., 2010). This comment concerns two topics addressed in the discussion section: 1) connection of their revised Rotterdam relative sea-level curve for the period 7900-5300 cal yr BP (MSL-R2; Jelgersma, 1961; Van de Plassche, 1982; 1995; Berendsen et al., 2007; Van de Plassche et al., 2010) to the sea-level curve for the same area for the period 9000-7500 cal yr BP (MSL-R1; Hijma \& Cohen, 2010); 2) The role of the river gradient on the calculation of the magnitude of a sea-level jump that occurred between 8450-8250 cal yr BP (Hijma \& Cohen, 2010).

\section{Preference for MSL-R1 or MSL-R2}

For the $8000-7500$ cal yr BP time frame, the two proposed curves have slightly different shapes. The difference is largest around $\sim 7900$ cal yr BP (sample H23, Hillegersberg site) where Van de Plassche et al. (2010) prefer a $\sim 50 \mathrm{~cm}$ lower mean sea-level position. The mismatch originates from differences in perception and calculation of the magnitude of the 'river gradient' and the 'tidal amplitude' at the time, leading to a different indicative range attributed to the sea-level index points. Hijma \& Cohen (2010) approach this forward in time and from downstream. In assigning an indicative range and quantifying vertical uncertainty they incorporated 1) land-inward dampening of the tides offshore (between 8000-7000 cal yr not yet the situation of the last $7000 \mathrm{yr}$; e.g. Van der Molen \& De Swart, 2001), 2) the transgressive palaeogeography of the estuary that linked water levels at sites such as Hillegersberg to the open sea in the period of interest (Hijma, 2009; Hijma et al., 2009; Hijma \& Cohen, 2011) and 3) the 3D distribution of peat radiocarbon dates and sedimentological criteria to recognize river gradient in space and exclude river-gradient affected index-points when reconstructing sea-level rise in time (Cohen, 2003; 2005; Hijma \& Cohen, 2010). Van de Plassche et al. (2010) approach this backward in time and from upstream to downstream. Most of their index points come from the period after 7500 cal yr when the study area became part of a barrier-protected lagoonal swamp area that could form because the rate of sea-level rise decreased and the Rhine had avulsed away from the area (Hijma $\&$ Cohen, 2011). The abundance of sites (e.g. Vlaardingen, Bolnes, Barendrecht) allowed site-to-site comparison and quantification of the 'floodbasin effect' and the 'river-gradient effect' to find out at which downstream site, at which time, the peat index points most closely resemble MSL. This is the body of the Van de Plassche et al. 2010 paper and a great achievement of Van de Plassche and co-workers in the 1980ies and 1990ies.

It is once step further, however, to extrapolate these insights from the lagoonal situation to an earlier time frame when the study area was part of the very wide Rhine-Meuse estuary. This step is attempted in the Evaluation and Discussion section, p.16-18 and Fig. 10 which evaluate the position of the mean groundwater table at site Polderweg / De Bruin above contemporary MSL at site Hillegersberg ( $20 \mathrm{~km}$ downstream) for the two competing RSL curves. It is claimed that the river-gradient effect steadily decreased from 1.4 to $0.9 \mathrm{~m}$ in the period 7800-6000 cal yr BP, and that such would be more logical than having a semi-stable elevation difference of $1 \mathrm{~m}$, with $\mathrm{dm}$-scale variations superimposed. This claim is based on data from the lagoonal period when, as sea level rose and a retrograding beach barrier had established (Hijma et al., 2010), the distance 
between the sampling sites and the tidal-inlet mouth(s) decreased and simultaneously also the river-gradient effect. However, as the palaeogeographical setting between 8500 7500 cal yr BP was very different downstream of Polderweg/De Bruin, one should not a-priori assume this relation to hold for the older situation where a wide and open estuary mouth existed amidst a less-developed and more-seaward barrier shoreline. It is entirely possible that between 8000-7500 cal yr BP sites Polderweg / De Bruin and the Hillegersberg were at similar distance to wide estuarine waters. Also, when an area such as the Rhine-Meuse valley is transgressed, groundwatertable gradients decrease strongly during the transformation from a valley to a peaty, tidally influenced estuary. As shown by Cohen (2005) and Hijma \& Cohen $(2010,2011)$ this change had occurred well before 8000 cal yr BP in the Rotterdam area. After the change and during the open estuarine situation that ended shortly after 7500 cal yr BP, one can exclude the river gradient to have remained an influence in the Polderweg / De Bruin and Hillegersberg area (upper estuary at the time, upstream limit of 'lower delta' cf. Cohen, 2005, downstream of the maximum floodbasin effect). Any groundwater surfacegradient effects present in the floodbasins of the area (e.g. the two scenarios in Fig. 10) would be due to Holocene deltaic processes (e.g. tidal-inlet reconfigurations, Van de Plassche, 1995, Cohen, 2005; river avulsion, Berendsen et al., 2007) and in the time frame of interest need not necessarily to obey a reducing trend. In our opinion, correcting for a river-gradient effect should be reserved for areas identified to be inland from the area with the maximum floodbasin effect.

A more excessive comment would boil down to a discussion of the indicative meaning assigned to one index point at Hillegersberg (H23), for which the error margins are of the same dm-magnitude as the evaluated differences between the curves in Fig. 10. It would also discuss the many uncertainties involved in modelling palaeotides. Both Hijma \& Cohen (2010) and Van de Plassche et al. (2010) used the results of Van der Molen \& De Swart (2001, see also Van der Molen \& Van Dijck, 2000) who used present-day bathymetry of the North Sea (corrected for land-movement in the last $8 \mathrm{ka}$ based on Lambeck, 1995). This inevitably results in large uncertainties, especially for a rapidly changing environment such as the middle Holocene Southern Bight and the Rhine-Meuse river-mouth area. Improved palaeotidal modelling using post-1995 insights in glacio-hydro-isostasy, ocean tides, palaeogeography and eustasy would be a step to resolve some of the problems and could potentially lead to dm-scale changes in the position of the MSL-curve. Besides that, the results of Van der Molen \& De Swart (2001) are for the offshore area. To obtain intra-coastal ranges we arbitrarily assumed 50\% damping, as did Van de Plassche et al. (2010). Because of the uncertainties involved, not only in the damping factor but also on the modeled open-sea values, the error band used in further calculations is $75 \%$ of the tidal amplitude. For example, for $7500 \mathrm{cal}$ yr BP we suggest that the intra-coastal tidal range lay anywhere between 0.2-1.2 m (Hijma \& Cohen, 2010; Suppl. Inf., Fig. DR4), but most likely around $0.8 \mathrm{~m}$ (See also Fig. 1). Van de Plassche et al. (2010) do not use any error margins around the tidal ranges they use, nor around their inferred river-gradient effects. If they would have done so, it would have been clear that one should avoid zooming in on dm-scale differences between MSL-curves without regarding the error envelop around the curves.

\section{Non-impact on $8.45 \mathrm{ka} 2.11 \pm 0.89 \mathrm{~m}$ sea-level jump calculations}

Whereas the above comments can be attributed to differences in interpretation, in the final part of the discussion, Van de Plassche et al. (2010) remark that their find of a significant river-gradient effect between Hillegersberg and Vlaardingen (mainly based on data younger than 7000 cal BP), can be

\section{Palaeotide history Rotterdam}

interval of interest to jump-magnitude calculations interval of interest to the paper of Van de Plassche et al. (2010)

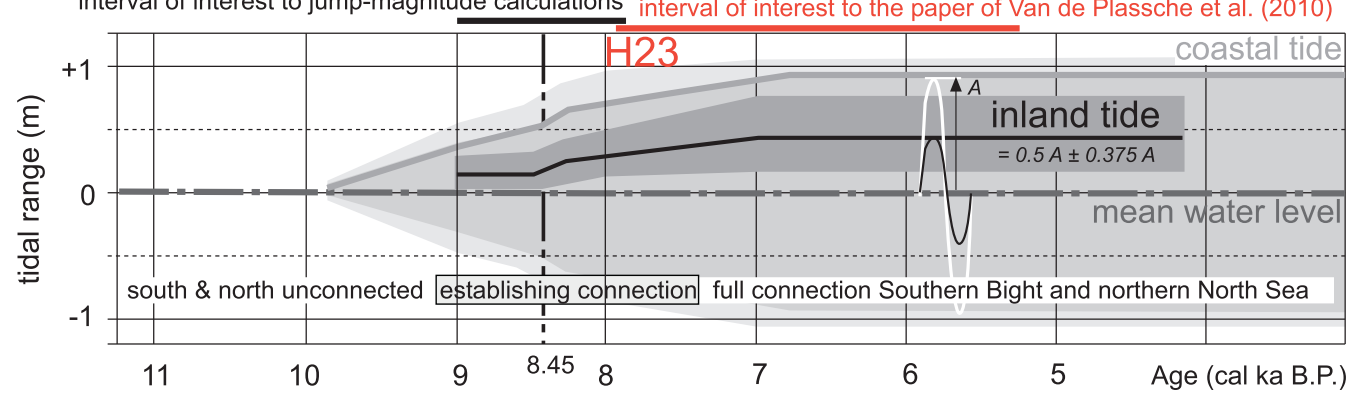

Fig. 1. The offshore tidal amplitude throughout the Holocene along the coast near Hoek van Holland (upper grey line, based on Van der Molen \& De Swart, 2001) along with the intervals of interest for Hijma \& Cohen (2010) and Van de Plassche et al. (2010). For the sample sites in the Rhine-Meuse estuary, we assumed the tidal amplitude (black line) to be half the offshore value due to the flood-basin effect and used that value in our calculations. Because of the many uncertainties involved, we set the uncertainty at $75 \%$ of the tidal amplitude at the sample location (or $37.5 \%$ of the offshore tidal amplitude). The development of the connection between the Southern Bight and the northern North Sea is based on a compilation of published articles Conradsen \& Heier-Nielsen (1995), Lambeck (1995), Jiang et al. (1997) and Van der Molen \& Van Dijck (2000). 
projected to the situation 8400 years ago and 'may account for a considerable part of the inferred sea-level jump of $2.11 \pm 0.89 \mathrm{~m}^{\prime}$ that was described in Hijma \& Cohen (2010). It also incorrectly stated that in their calculations, Hijma \& Cohen (2010) supposed a zero river-gradient situation over $32 \mathrm{~km}$ inland distance. This part of the 'Evaluation and discussion' seriously misrepresents our methodology.

The calculation of the magnitude of the jump is based on a downstream pre-jump dataset (Maasvlakte) and a post-jump dataset $32 \mathrm{~km}$ inland (Rotterdam). In their Supplementary Information Hijma \& Cohen (2010) describe how the rivergradient was treated in the dataset. Prior to the jump, our inland site around Rotterdam was affected by the valley-topography inherited river gradient, with floodbasin groundwater tables well above contemporary MSL. Hijma \& Cohen (2010: their Fig. 1) show that between 9000 and 8500 the floodbasin peats at Rotterdam lie at $16 \mathrm{~m}$-NAP, about $4 \mathrm{~m}$ above the contemporary peats at the Maasvlakte, implying a river gradient effect of $\sim 0.12 \mathrm{~m} / \mathrm{km}$. However, this does not affect the calculation of the magnitude, as the pre-jump and post-jump datasets have different ages. The valley-inherited gradient was to be completely overcome by the sea-level rise that would follow, including that of the sea-level jump. Palaeoenvironmental indicators show that the dated peats of both datasets formed in the same sort brackish to fresh tidal environment, indicative of broad occurrence of open water and accommodation-outpaced sedimentation. In that situation, which differs greatly from the 7000-5300 cal yr BP situation on which Van de Plassche et al. (2010) base their inferences, it is unrealistic to assume significant river gradients to be in play. Even if one would want to correct the index points for a river-gradient effect, one should not look at the distance between the downstream and upstream site as the datasets from those sites have different ages. One should look at the environment in which the dated organics formed. As the pre-jump and post-jump datasets come from very similar upper estuarine environments, the rivergradient would have been the same and the magnitude of the sea-level jump would not change. Would one want to correct for a floodbasin effect in this environment, one should also use the same value in both cases. The latter is what Hijma \& Cohen (2010) did, with their 50\% $\pm 37.5 \%$ tidal dampening.

Also the discussion by Van de Plassche et al. (2010) of the indicative range of $\mathrm{H} 23$ and the difference between curves MSL-R1/R2 has no impact on the sea-level jump calculations in Hijma \& Cohen (2010). Input to that calculation was:

1. A value for total relative sea level rise, $4.06 \pm 0.5 \mathrm{~m}$ between $8495 \pm 50$ and $8298 \pm 55$ cal yr, based on samples \#18/19 and $\# 10$, from 19.6 and $16.3 \mathrm{~m}$-NAP respectively. None of these values/samples/dates are affected by the data or the discussed issues in the Van de Plassche et al. (2010) paper.

2. A value for the rate of then ongoing background relative sea-level rise, set at $10 \pm 1.5 \mathrm{~mm} / \mathrm{yr}$. This value and associated error were achieved through assessment of index-points from the centuries after the jump, with $\mathrm{H} 23$ being the youngest sample considered (Hijma \& Cohen, 2010: Table S3), by assessing index-points from the five centuries before the jump, and by assessing the regional data sets and literature. Lowering the indicative range of index point $\mathrm{H} 23$ by $50 \mathrm{~cm}$ would modestly reduce post-jump background rate, but it would remain within the $10 \pm 1.5 \mathrm{~mm} / \mathrm{yr}$ range, adding support to the use of that value and the associated error range.

\section{Conclusion}

We have submitted this paper to NJG for three reasons:

- Our comment on the introduction of curve MSL-R2 next to MSL-R1 by Van de Plassche et al. 2010 (their Fig. 9) is that we consider both curves to be within the error at which MSL is currently resolved for the period 8000-7500. For the same reason, Fig. 10 is considered a weak tool for evaluating the relative validity of MSL-R2 versus MSL-R1, also because it launches false theoretic criterions in the form of presumed river-gradient effect evolution.

- In contrast to what Van de Plassche et al. (2010) suggest, their results regarding floodbasin and river-gradient effect have no impact on the jump-magnitude calculations in Hijma \& Cohen (2010). The latter study is based on sea-level rise acceleration and deceleration $600-400$ yr before the oldest date from Van de Plassche et al. (2010), at depths 3 to 8 meters closer to the base of the Holocene than the deepest sample from Van de Plassche et al. (2010) and from a rapidly drowning and inland shifting upper estuarine setting with increasing tidal ranges, instead of the protected lagoonal setting with stabilizing tidal ranges in which most of the dated organics of Van de Plassche et al. (2010) accumulated.

- Inferences regarding gradients in floodbasin water levels from times between 7000 to $5300 \mathrm{cal}$ yr BP have no meaning for would-be river gradients in much earlier times, because of the great palaeogeographical differences.

We regret the loss of Orson van de Plassche for the sea-level research community in general, and that in the Rhine-Meuse delta in particular, and apologize for commenting on a posthumous paper, having to act on a misrepresentation of our methodology. We regard it very important to unify sea-level rise datasets and concepts from the drowning estuarine Holocene delta base with that of the overlying back-barrier protected setting. This comment is written in that spirit. 


\section{References}

Berendsen, H.J.A., Makaske, B., Van de Plassche, O., Van Ree, M.H.M., Das, S., Van Dongen, M., Ploumen, S. \& Schoenmakers, W., 2007. New groundwaterlevel rise data from the Rhine-Meuse delta - implications for the reconstruction of Holocene relative mean sea-level rise and differential land-level movements. Netherlands Journal of Geosciences - Geologie en Mijnbouw 86 (4): 333-354.

Cohen, K.M., 2003. Differential subsidence within a coastal prism. Late-Glacial Holocene tectonics in the Rhine-Meuse delta, The Netherlands. Ph.D.-thesis, Utrecht University, $176 \mathrm{pp}$.

Cohen, K.M., 2005. 3D geostatistical interpolation and geological interpolation of palaeo-groundwaterrise within the coastal prism in the Netherlands. In: Giosan, L. \& Bhattacharaya, J.P. (eds): River Deltas: Concepts, models, and examples SEPM (Society for Sedimentary Geology) (Tulsa, 0klahoma, USA): 341-364.

Conradsen, K. \& Heier-Nielsen, S., 1995. Holocene paleoceanography and paleoenvironments of the Skagerrak-Kattegat, Scandinavia. Paleoceanography 10 (4): 801-813. doi: 10.1029/95PA01142.

Hijma, M.P., 2009. From river valley to estuary: the early-mid Holocene transgression of the Rhine-Meuse valley, the Netherlands. Ph.D.-thesis, Utrecht University (Utrecht, the Netherlands), $192 \mathrm{pp}$. Download at: igitur-archive.library.uu.nl/dissertations/2009-1209-200111/UUindex.html.

Hijma, M.P. \& Cohen, K.M., 2010. Timing and magnitude of the sea-level jump preluding the $8200 \mathrm{yr}$ event. Geology 38 (3): 275-278. doi: 10.1130/G30439.1.

Hijma, M.P. \& Cohen, K.M., 2011. Holocene transgression of the Rhine river mouth area, the Netherlands / Southern North Sea: palaeogeography and sequence stratigraphy. Sedimentology. doi: 10.1111/j.1365-3091.2010.01222.x.

Hijma, M.P., Cohen, K.M., Hoffmann, G., Van der Spek, A.J.F. \& Stouthamer, E., 2009. From river valley to estuary: the evolution of the Rhine mouth in the early to middle Holocene (western Netherlands, Rhine-Meuse delta). Netherlands Journal of Geosciences - Geologie en Mijnbouw 88 (1): 13-53..

Hijma, M.P., Van der Spek, A.J.F. \& Van Heteren, S., 2010. Development of a mid-Holocene estuarine basin, Rhine-Meuse mouth area, offshore the Netherlands. Marine Geology 271 (3-4): 198-211. doi: 10.1016/j.margeo. 2010.02.011.

Jelgersma, S., 1961. Holocene sea-level changes in the Netherlands. Mededelingen Geologische Stichting 7: 1-101.

Jiang, H., Björck, S. \& Knudsen, K.L., 1997. A palaeoclimatic and palaeoceanographic record of the last $11,000{ }^{14} \mathrm{C}$ years from the Skagerrak-Kattegat, northeastern Atlantic margin. The Holocene 7 (3): 301-310. doi: 10.1177/ 095968369700700306.

Lambeck, K., 1995. Late Devensian and Holocene shorelines of the British Isles and North Sea from models of glacio-hydro-isostatic rebound. Journal of the Geological Society 152: 437-448. doi: 10.1144/gsjgs.152.3.0437.

Van de Plassche, 0., 1982. Sea-level change and water-level movements in the Netherlands during the Holocene. Ph.D.-thesis, Vrije Universiteit (Amsterdam), $93 \mathrm{pp}$.

Van de Plassche, 0., 1995. Evolution of the intra-coastal tidal range in the Rhine-Meuse delta and Flevo Lagoon, 5700-3000 yr cal BC. Marine Geology 124 (1-4): 113-128. doi: 10.1016/0025-3227(95)00035-W.
Van de Plassche, O., Makaske, B., Hoek, W.Z., Konert, M. \& Van der Plicht, J., 2010. Mid-Holocene water-level changes in the lower Rhine-Meuse delta (western Netherlands): implications for the reconstruction of relative mean sea-level rise, palaeoriver-gradients and coastal evolution. Netherlands Journal of Geosciences - Geologie en Mijnbouw 89 (1): 3-20.

Van der Molen, J. \& De Swart, H.E., 2001. Holocene tidal conditions and tideinduced sand transport in the southern North Sea. Journal of Geophysical Research C 106: C5, 9339-9362. doi: 10.1029/2000JC000488.

Van der Molen, J. \& Van Dijck, B., 2000. The evolution of the Dutch and Belgian coasts and the role of sand supply from the North Sea. Global and Planetary Change 27 (1-4): 223-244. doi: 10.1016/S0921-8181(01)00068-6. 